\title{
Variable $\mathrm{Na}_{\mathrm{v}} 1.5$ Protein Expression from the Wild-Type Allele Correlates with the Penetrance of Cardiac Conduction Disease in the Scn5a ${ }^{+/-}$Mouse Model
}

\author{
Anne-Laure Leoni ${ }^{1,3}$, Bruno Gavillet ${ }^{10}$, Jean-Sébastien Rougier ${ }^{5}$, Céline Marionneau ${ }^{1,3}$, Vincent \\ Probst $^{1,2,3,4}$, Solena Le Scouarnec ${ }^{1,2,3}$, Jean-Jacques Schott ${ }^{1,2,3,4}$, Sophie Demolombe ${ }^{1,2,3}$, Patrick \\ Bruneval $^{6}$, Christopher L. H. Huang ${ }^{8}$, William H. Colledge ${ }^{8}$, Andrew A. Grace ${ }^{8}$, Hervé Le Marec ${ }^{1,2,3,4}$, \\ Arthur A. Wilde ${ }^{7}$, Peter J. Mohler ${ }^{9}$, Denis Escande ${ }^{1,3,4 \dagger}$, Hugues Abriel ${ }^{5}$, Flavien Charpentier ${ }^{1,2,3,4_{*}}$
}

1 INSERM, UMR915, I'Institut du Thorax, Nantes,France, 2 CNRS, ERL3147, Nantes, France, 3 Universite de Nantes, Nantes, France, 4 CHU Nantes, I'Institut du Thorax, Nantes, France, 5 Department of Clinical Research, University of Bern, Bern, Switzerland, 6 INSERM, U652, Université Paris V, Paris, France, 7 Department of Cardiology, Academic Medical Center, Amsterdam, The Netherlands, 8 The Section of Cardiovascular Biology, Departments of Biochemistry and Physiology, University of Cambridge, Cambridge, United Kingdom, 9 Department of Internal Medicine, University of lowa Carver College of Medicine, lowa City, lowa, United States of America, 10 Department of Pharmacology and Toxicology, University of Lausanne, Lausanne, Switzerland

\begin{abstract}
Background: Loss-of-function mutations in SCN5A, the gene encoding $\mathrm{Na}_{\mathrm{v}} 1.5 \mathrm{Na}^{+}$channel, are associated with inherited cardiac conduction defects and Brugada syndrome, which both exhibit variable phenotypic penetrance of conduction defects. We investigated the mechanisms of this heterogeneity in a mouse model with heterozygous targeted disruption of $\mathrm{Scn} 5 a\left(\mathrm{Scn} 5 a^{+/-}\right.$mice) and compared our results to those obtained in patients with loss-of-function mutations in SCN5A.

Methodology/Principal Findings: Based on ECG, 10-week-old Scn5a ${ }^{+/-}$mice were divided into 2 subgroups, one displaying severe ventricular conduction defects (QRS interval $>18 \mathrm{~ms}$ ) and one a mild phenotype (QRS $\leq 18 \mathrm{~ms} ; \mathrm{QRS}$ in wild-type littermates: 10-18 ms). Phenotypic difference persisted with aging. At 10 weeks, the $\mathrm{Na}^{+}$channel blocker ajmaline prolonged QRS interval similarly in both groups of $S \mathrm{cn} 5 a^{+/-}$mice. In contrast, in old mice ( $>53$ weeks), ajmaline effect was larger in the severely affected subgroup. These data matched the clinical observations on patients with SCN5A loss-offunction mutations with either severe or mild conduction defects. Ventricular tachycardia developed in $5 / 10$ old severely affected Scn5a $\mathrm{a}^{+/-}$mice but not in mildly affected ones. Correspondingly, symptomatic SCN5A-mutated Brugada patients had more severe conduction defects than asymptomatic patients. Old severely affected $\mathrm{Scn} 5 \mathrm{a}^{+/-}$mice but not mildly affected ones showed extensive cardiac fibrosis. Mildly affected $\mathrm{Scn} 5 a^{+/-}$mice had similar $\mathrm{Na}_{\mathrm{v}} 1.5 \mathrm{mRNA}$ but higher Na 1.5 protein expression, and moderately larger $I_{\mathrm{Na}}$ current than severely affected $\operatorname{Scn} 5 a^{+/-}$mice. As a consequence, action potential upstroke velocity was more decreased in severely affected $\operatorname{Scn} 5 \mathrm{a}^{+/-}$mice than in mildly affected ones.
\end{abstract}

Conclusions: Scn5a $a^{+/-}$mice show similar phenotypic heterogeneity as SCN5A-mutated patients. In Scn5a ${ }^{+/-}$mice, phenotype severity correlates with wild-type $\mathrm{Na}_{\mathrm{v}} 1.5$ protein expression.

Citation: Leoni A-L, Gavillet B, Rougier J-S, Marionneau C, Probst V, et al. (2010) Variable Nav1.5 Protein Expression from the Wild-Type Allele Correlates with the Penetrance of Cardiac Conduction Disease in the Scn5a ${ }^{+/-}$Mouse Model. PLoS ONE 5(2): e9298. doi:10.1371/journal.pone.0009298

Editor: Maurizio C. Capogrossi, Istituto Dermopatico dell'Immacolata, Italy

Received September 22, 2009; Accepted February 1, 2010; Published February 19, 2010

Copyright: (C) 2010 Leoni et al. This is an open-access article distributed under the terms of the Creative Commons Attribution License, which permits unrestricted use, distribution, and reproduction in any medium, provided the original author and source are credited.

Funding: This work was supported by grants from the Agence Nationale de la Recherche, Paris, France (ANR-05-PCOD-037-01 for FC; ANR-05-MRAR-028 for JJS and DE), the Fondation Leducq, Paris, France (DE, JJS, AAW), the Netherlands Heart Foundation, Den Haag, The Netherlands (2003/B195 for AAW), the National Institutes of Health, Bethesda, Maryland, United States of America (NIH R01 HL083422 for PJM) and the Swiss National Science Foundation, Bern, Switzerland (310000-120707 for HA). The funders had no role in study design, data collection and analysis, decision to publish, or preparation of the manuscript.

Competing Interests: The authors have declared that no competing interests exist.

* E-mail: flavien.charpentier@nantes.inserm.fr

$\dagger$ Deceased.

\section{Introduction}

The cardiac voltage-gated $\mathrm{Na}^{+}$channel $\mathrm{Na}_{\mathrm{v}} 1.5$, encoded by SCN5A gene, determines the upstroke velocity of the action potential and, in conjunction with gap junction channels and the organization of the collagenous skeleton, controls the propagation of the cardiac electrical impulse. Loss-of-function mutations of $S C N 5 A$ are associated to the inherited form of progressive cardiac conduction defect $[1,2]$ (PCCD) and to the Brugada syndrome (BrS) [3-5]. In patients with inherited PCCD, the conduction of the cardiac impulse is abnormally slow and becomes progressively slower with aging leading ultimately to atrioventricular block and pacemaker implantation in the elderly [2]. The presence of conduction defects is also one striking feature of $\mathrm{BrS} S C N 5 A$-mutation carriers [6,7]. As for most inherited electrical cardiac diseases, penetrance of the defect caused by $S C N 5 \mathrm{~A}$ haploinsufficiency is variable among carriers of the same mutation, with patients showing severe conduction alterations and others exhibiting an almost normal phenotype [2]. This demonstrates that 
factors independent of the morbid gene exert considerable influence on outcome of the inherited "channelopathy". One obvious possibility in humans is the contribution of "modifier genes", which could control expressivity of the monogenic defect [8].

A mouse model with targeted disruption of $\operatorname{Sin} 5 a$ has been established [9]. In previous works [10,11], we showed that heterozygous $\operatorname{Scn} 5 a$ deficient $\left(S c n 5 a^{+/-}\right)$mice convincingly recapitulate PCCD phenotype including progressive impairment of atrial and ventricular conduction with aging. Because progressive decline in conduction velocity is also associated with myocardial rearrangements and fibrosis, we provided the first demonstration that an isolated ion channel defect can lead to myocardial structural anomalies [10]. In the present study, we demonstrate that: (i) the expression of the conduction anomalies is variable among inbred Scn5a $a^{+/-}$mice; (ii) $S c n 5 a^{+/-}$mice with severe conduction defects (severe phenotype) exhibit more myocardial rearrangements with aging than mice with mild conduction defects (mild phenotype); (iii) old mice with a severe, but not with a mild phenotype, have a markedly reduced conduction reserve and show spontaneous ventricular arrhythmias; (iv) similarly, symptomatic $\mathrm{BrS}$ patients carrying SCN5A mutations have more pronounced conduction slowing than asymptomatic patients; and, (v) in mice, the expression of the phenotype correlates with the ability of the normal allele to produce at the post-transcriptional level variable amount of functional $\mathrm{Na}_{\mathrm{v}} 1.5$ channel proteins.

\section{Results}

Heterogeneity of the Intraventricular Conduction Defect in $\mathrm{Scn} 5 \mathrm{a}^{+/-}$Mice

Young adult (10-12 week-old) $S c n 5 a^{+/-}$mice were investigated for their ventricular conduction parameters. Figure 1A shows representative ECG recordings from a WT and two $\operatorname{Scn} 5 a^{+/-}$mice. The two $\operatorname{Sin} 5 a^{+/-}$mice clearly differed since one exhibited a markedly prolonged QRS complex whereas the other had a relatively normal one. Figure 1B displays the QRS interval distribution in 84 WT littermates and $136 \mathrm{Scn}_{5 a^{+/-}}$young adult mice. Statistical analysis showed that the QRS interval duration was not normally distributed in the $\operatorname{Scn} 5 a^{+/-}$population but distributed according to two subgroups, (i) one with a severe conduction phenotype $(\mathrm{QRS}>18 \mathrm{~ms}$; mean $\mathrm{QRS}=22 \pm 0 \mathrm{~ms}$; range 19-26 ms; $\mathrm{n}=63$ ), and (ii) the other with a mild conduction phenotype $(\mathrm{QRS} \leq 18 \mathrm{~ms}$; mean $\mathrm{QRS}=15 \pm 0 \mathrm{~ms}$; range $12-18 \mathrm{~ms} ; \mathrm{n}=73$; $\mathrm{p}<0.05$ versus WT and severe phenotype). In the WT littermate population, QRS duration ranged from 10 to $18 \mathrm{~ms}$ (mean QRS $=13 \pm 0 \mathrm{~ms}$ ). Each group (WT, mild and severe) differed significantly from the two others with $\mathrm{p}$ values $<0.001$. Phenotype severity in $\operatorname{Scn} 5 a^{+/-}$mice was not influenced by gender (male/female ratio: $43 / 30$ and $31 / 32$ in mice with mild and severe conduction defects, respectively; NS). Moreover, among the 25 litters in which all $S c n 5 a^{+/-}$mice have been phenotyped, the average proportion of mice with mild conduction defects was $0.53 \pm 0.05$ (NS versus theoretical proportion of 0.5). In 2 litters, all $\operatorname{Scn} 5 a^{+/-}$mice had mild conduction defects ( 2 and 3 mice, respectively). In 2 others, all $\operatorname{Scn} 5 a^{+/-}$mice had, in contrast, severe conduction defects (3 mice in each). Thus, based on the QRS duration, we distinguished 3 groups of mice: WT mice, $S c n 5 a^{+/-}$mice with a mild phenotype, i.e. with a small QRS prolongation, and $S_{c n} 5 a^{+/-}$mice with a severe phenotype, i.e. with a marked QRS prolongation.

Subpopulations of these 3 groups were included in a longitudinal study conducted up to the age of 80 weeks. There was a progressive increase in QRS interval with age in WT and $\operatorname{Scn} 5 a^{+>-}$mice, although this increase was slightly more pronounced in $\operatorname{Scn} 5 a^{+/-}$mice, thus confirming previous results

A

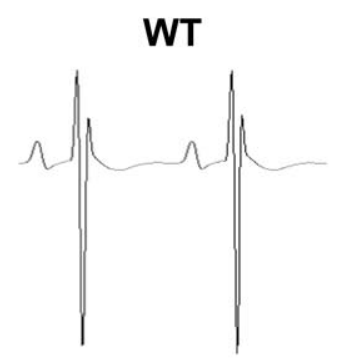

B

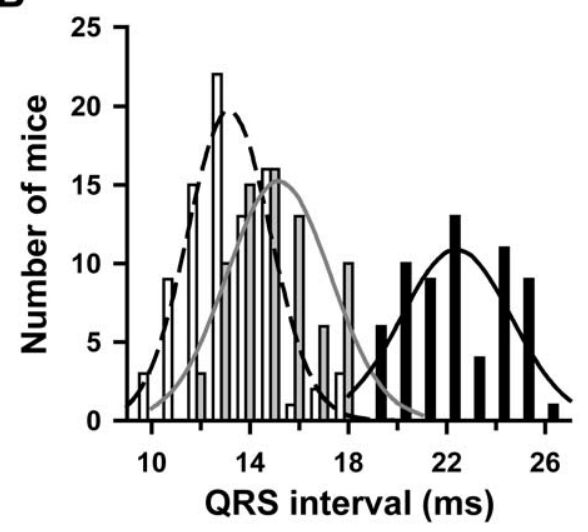

Mild

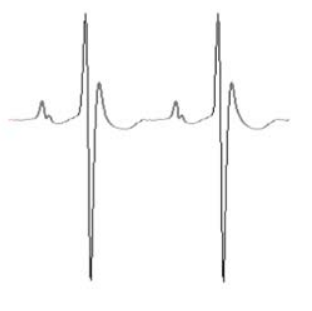

C

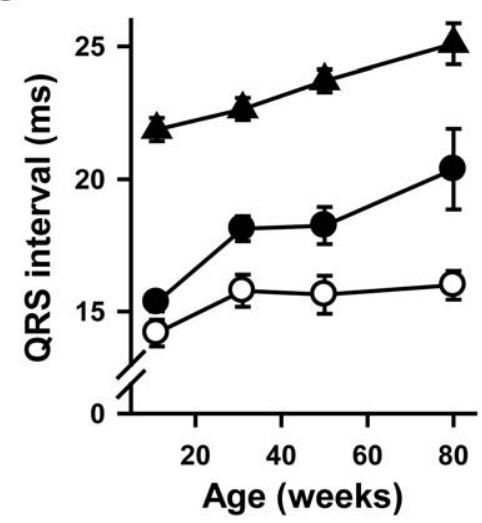

Figure 1. Variable degrees of ventricular conduction defects in Scn5a $a^{+/-}$mice. A. Representative lead I ECGs from 10 week-old wild-type (WT) mice and Scn5a ${ }^{+/-}$mice with mild and severe conduction defects. Scale bar, $100 \mathrm{~ms}$. B. Distribution of QRS interval duration with corresponding Gaussian fits in 10 week-old WT mice (white bars) and Scn5a $a^{+-}$mice with mild (grey bars) and severe (black bars) phenotype. C. Effects of age (X-axis) on QRS interval duration (Y-axis) in WT mice (open symbols) and $\mathrm{Scn} 5 \mathrm{a}^{+/-}$mice with mild (filled circles) and severe (filled triangles) phenotype. See Table 1 for statistics. doi:10.1371/journal.pone.0009298.g001 
Table 1. ECG characteristics of wild-type (WT) and $\operatorname{Scn} 5 a^{+/-}$mice with mild and severe phenotype.

\begin{tabular}{|c|c|c|c|c|c|c|c|c|}
\hline & $\mathbf{n}$ & Age (weeks) & RR (ms) & $\mathbf{P}(\mathbf{m s})$ & PR (ms) & QRS (ms) & QT (ms) & QTc \\
\hline \multirow[t]{4}{*}{ WT } & 16 & $11 \pm 0$ & $128 \pm 3$ & $15 \pm 0$ & $35 \pm 1$ & $14 \pm 1$ & $64 \pm 1$ & $58 \pm 1$ \\
\hline & 14 & $31 \pm 0$ & $122 \pm 3$ & $16 \pm 1$ & $34 \pm 1$ & $16 \pm 1$ & $60 \pm 2$ & $54 \pm 1$ \\
\hline & 14 & $50 \pm 1$ & $122 \pm 3$ & $16 \pm 1$ & $35 \pm 1$ & $16 \pm 1$ & $58 \pm 1$ & $53 \pm 1$ \\
\hline & 12 & $81 \pm 3$ & $115 \pm 1^{\S \S \S}$ & $15 \pm 1$ & $34 \pm 1$ & $16 \pm 1$ & $58 \pm 1^{\S}$ & $54 \pm 1$ \\
\hline \multirow[t]{4}{*}{ Mild Scn5a } & 20 & $12 \pm 1$ & $135 \pm 3$ & $18 \pm 1^{* *}$ & $39 \pm 1 * * *$ & $15 \pm 0$ & $67 \pm 1$ & $58 \pm 1$ \\
\hline & 16 & $31 \pm 0$ & $127 \pm 2$ & $18 \pm 1$ & $39 \pm 1 * * *$ & $18 \pm 0^{* * \S \S}$ & $61 \pm 2^{\S \S}$ & $54 \pm 1^{\S \S}$ \\
\hline & 16 & $49 \pm 1$ & $130 \pm 3$ & $18 \pm 0^{*}$ & $40 \pm 1 * * *$ & $18 \pm 1^{* * \S \S \S}$ & $61 \pm 1^{\S \S}$ & $53 \pm 1^{\S \S}$ \\
\hline & 8 & $78 \pm 5$ & $132 \pm 2^{* *}$ & $19 \pm 1^{*}$ & $42 \pm 2 * * *$ & $20 \pm 2^{* * * \S \S \S}$ & $66 \pm 2^{* *}$ & $57 \pm 1$ \\
\hline \multirow[t]{4}{*}{ Severe Scn5at- } & 17 & $11 \pm 1$ & $142 \pm 4^{* * *}$ & $18 \pm 0^{*}$ & $39 \pm 1 * * *$ & $22 \pm 0^{* * *^{\dagger}}$ & $69 \pm 1^{*}$ & $59 \pm 1$ \\
\hline & 17 & $32 \pm 0$ & $128 \pm 2^{\S \S}$ & $19 \pm 1^{*}$ & $38 \pm 1 * * *$ & $23 \pm 0^{* * * \dagger}$ & $63 \pm 1^{\S \S}$ & $55 \pm 1$ \\
\hline & 17 & $50 \pm 2$ & $124 \pm 2^{\S \S \S}$ & $18 \pm 0^{* * *}$ & $39 \pm 1 * * *$ & $24 \pm 0^{* * * *^{\dagger}}$ & $62 \pm 1^{\S \S}$ & $56 \pm 1$ \\
\hline & 10 & $80 \pm 3$ & $128 \pm 2^{*}$ & $19 \pm 1^{* *}$ & $43 \pm 1^{* * * \$ \$}$ & $25 \pm 1^{* * * \dagger \S \S}$ & $68 \pm 2^{* * *}$ & $59 \pm 1 *$ \\
\hline
\end{tabular}

Abbreviations: $n$, number of animals per group; RR, RR interval duration; P, P wave duration; PR, PR interval duration; QRS, QRS complex duration; QT, QT interval duration; QTc, corrected QT interval duration.

Data are mean \pm sem. ${ }^{*}, * *, * * *, p<0.05, p<0.01$ and $\mathrm{p}<0.001$ respectively versus $\mathrm{WT}$ (matching age); ${ }^{\dagger}, \mathrm{p}<0.001$ versus Mild (matching age); ${ }^{\S}{ }^{\S \S},{ }^{\S \S}, \mathrm{p}<0.05, \mathrm{p}<0.01$ and $\mathrm{p}<0.001$ respectively versus youngest age in each group.

doi:10.1371/journal.pone.0009298.t001

(Figure 1C) [10]. Among Scn5a $a^{+/-}$mice, the difference in phenotype was maintained over time: each mouse remained in its initial group. Atrial and atrioventricular conduction (as evaluated respectively by $\mathrm{P}$ wave and $\mathrm{PR}$ interval durations) were similar in the two groups of $\operatorname{Scn} 5 a^{+/-}$mice and significantly slower than in WT mice (Table 1).

\section{Reduced Conduction Reserve in Scn5a $a^{+/-}$Mice and} Patients with SCN5A Mutations with a Severe Phenotype

To estimate their conduction reserve, we challenged young (10 weeks) and old (>53 weeks) Scn $5 a^{+/-}$mice with the $\mathrm{Na}^{+}$channel blocker ajmaline $(20 \mathrm{mg} / \mathrm{kg}$ i.p.). As shown in Figure 2, in young mice, the effects of ajmaline on the QRS interval were modest and similar in the two subgroups of $\operatorname{Scn} 5 a^{+/-}$mice $(+10.4 \pm 2.0 \mathrm{~ms}$ versus $+10.4 \pm 1.2 \mathrm{~ms}$ in mice with mild and severe phenotype, respectively). In old mice, ajmaline prolonged more the QRS interval in animals with a severe phenotype $(+12.0 \pm 0.8 \mathrm{~ms})$ than in animals with a mild phenotype $(+9.6 \pm 0.7 \mathrm{~ms} ; \mathrm{p}<0.05)$.

These mouse data were similar to the results of ajmaline tests performed in patients from Nantes cohort diagnosed with either PCCD or BrS and carrying mutations on SCN $5 A$ gene. These patients were separated in two groups based on the duration of QRS interval under baseline conditions: one with mild conduction defects (baseline QRS $\leq 108 \mathrm{~ms}$ ) and one with severe conduction defects (QRS>108 ms; see methods section for the cutoff value definition). As shown in Figure 2B, the ajmaline-induced QRS prolongation in aged patients was more pronounced in those with severe conduction defects under baseline conditions $(+55 \pm 7 \mathrm{~ms})$ than in those with mild conduction defects $(+34 \pm 5 \mathrm{~ms} ; \mathrm{p}<0.05)$. In contrast, no statistical difference was seen in the younger patients.

Thus, the conduction reserve is reduced with aging both in mice and humans with markedly prolonged QRS interval.

\section{Extensive Cardiac Fibrosis in the Ventricular Myocardium of Scn5a $a^{+-}$Mice with a Severe Phenotype}

Previously, we showed that heterozygous $\operatorname{Scn} 5 a$ invalidation in mouse produces ventricular rearrangements and fibrosis with aging $[10,11]$. We also showed that two transcription factors, Atf3, a stress-inducible gene, and $\operatorname{Egr} 1$, an early growth response gene, were up-regulated with aging in $S_{c n} 5 a^{+/-}$mice. Ventricular sections were evaluated for the presence of fibrosis in $83 \pm 3$ week-old mice. The investigator was blinded to genotype and phenotype. $S c n 5 a^{+/-}$mice with a severe phenotype were characterized by extensive fibrosis located in the left ventricular free wall and intraventricular septum (Figure 3A). In contrast, fibrosis in $\operatorname{Scn} 5 a^{+/-}$mice with a mild phenotype when present was restricted to small areas. Semi-quantitative assessment of cardiac

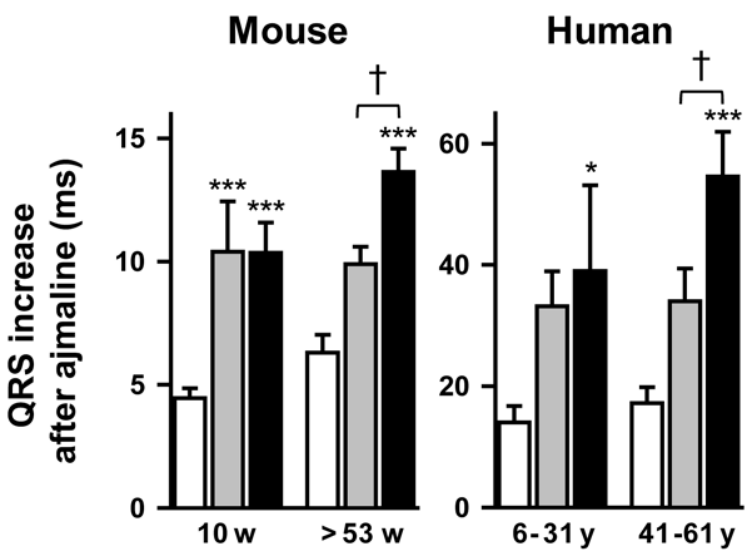

Figure 2. Variable effects of $\mathrm{Na}^{+}$channel blockade in $\mathrm{Scn} 5 a^{+/-}$ mice and SCN5A-mutated patients. Ajmaline-induced increase in QRS interval (Y-axes) in 10 week- and $>53$ week-old WT $(n=11$ and $n=10$; open bars), mildly ( $n=10$ and $n=10$; grey bars) and severely $\left(\mathrm{n}=11\right.$ and $\mathrm{n}=10$; black bars) affected $\mathrm{Scn} 5 \mathrm{a}^{+-}$mice (left panel), and in young (6-31 years; mean $=22$ years) and older (41-61 years; mean $=50$ years) non-mutated ( $n=18$ and $n=17$, open bars) and SCN5A-mutated patients with either mild ( $n=12$ and $n=11$; grey filled bars) or severe $(n=7$ and $n=12$; black filled bars) QRS interval prolongation (right panel). ****, $p<0.05$ and $\mathrm{p}<0.001$ respectively versus WT mice or nonmutated patients. $\dagger, \mathrm{p}<0.05$ versus $\mathrm{SCn} 5 \mathrm{a}^{+/-}$mice or SCN5A-mutated patients with a mild phenotype. The difference between old mildly affected mice and old WT mice did not reach significance $(p=0.07)$. Same comment for the older patients. doi:10.1371/journal.pone.0009298.g002 
A

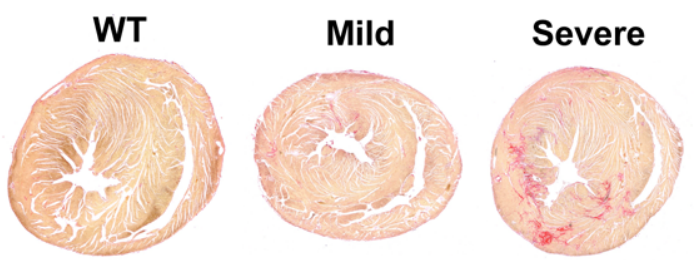

B

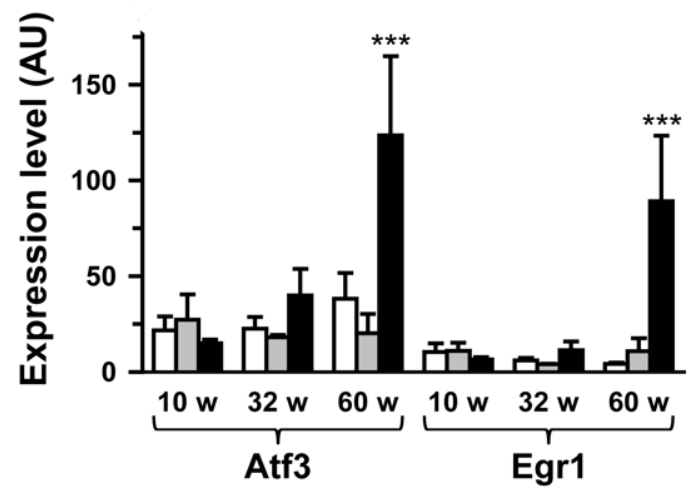

Figure 3. Variable levels of fibrosis in $S \mathrm{Cn} 5 \mathrm{a}^{+/-}$mice. A. Sirius red staining of ventricle from 85 week-old WT, mildly and severely affected Scn5a $a^{+-}$mice. Fibrosis appears in red. A score of 0 was attributed to the WT mouse shown, 1 to the mild $\operatorname{Scn} 5 a^{+/-}$mouse and respectively 2 and 3 to left and right severe $\mathrm{Scn} 5 \mathrm{a}^{+/-}$mice. B. Atf3 and Egr1 mRNA ventricular levels (in arbitrary units) in WT (open bars), mildly (grey bars) and severely (black bars) affected $S \mathrm{Cn} 5 \mathrm{a}^{+/-}$mice as a function of age. ***, $\mathrm{p}<0.001$ versus $\mathrm{WT}$ and mild.

doi:10.1371/journal.pone.0009298.g003

fibrosis led to mean scores of $1.88 \pm 0.40$ in $\operatorname{Scn} 5 a^{+/-}$mice with severe phenotype $(\mathrm{n}=8 ; \mathrm{p}<0.05$ versus WT), $0.60 \pm 0.40$ in $\operatorname{Scn} 5 a^{+/-}$mice with mild phenotype $(\mathrm{n}=5)$ and $0.25 \pm 0.25$ in WT mice $(\mathrm{n}=4)$. No fibrosis was observed in the right ventricular outflow tract region of $\operatorname{Scn} 5 a^{+/-}$mice with a severe phenotype (not shown). The transcription factors Atf3 and $E g r 1$ were exclusively over-expressed in old $\operatorname{Scn} 5 a^{+/-}$mice with a severe phenotype (Figure 3B).
Ventricular Arrhythmias in Scn5a $a^{+/-}$Mice with a Severe Phenotype and Wider QRS Interval in Symptomatic SCN5A-Related BrS Patients

With aging, $\operatorname{Scn} 5 a^{+/-}$mice with a severe phenotype had an increased propensity to develop spontaneous ventricular arrhythmias under anesthesia $(5 / 10)$ in comparison to $\operatorname{Scn} 5 a^{+/-}$mice with a mild phenotype $(0 / 8 ; \mathrm{p}<0.05)$ and WT mice $(0 / 12 ; \mathrm{p}<0.05)$. The severity of the arrhythmias ranged from ventricular extrasystoles to salvoes of ventricular tachycardia (Figure 4).

Patients from Nantes database with $S C N 5 A$-related $\mathrm{BrS}$ were pooled with their counterparts from Amsterdam database. Symptomatic patients, defined as having a clinical history of collapses, syncopes, documented ventricular tachycardia (and/or fibrillation) or aborted sudden death, were characterized by a longer QRS interval than asymptomatic patients (Table 2).

Differential Transcriptional Remodeling between Mild and Severe Phenotype Scn5a $a^{+/-}$Mice

We then investigated the molecular mechanisms potentially accounting for variable penetrance in $S c n 5 a^{+/-}$mice. We first hypothesized that molecular remodeling of ion channel gene expression could variably modulate the deficit. Figure 5 shows variations of expression of 46 ion-channel subunits in the ventricles of 10 week-old $S c n 5 a^{+/-}$mice relative to their expression in WT littermates. $\mathrm{Na}_{\mathrm{v}} 1.5$ transcripts were similarly down-regulated by almost $50 \%$ in $S_{c n} 5 a^{+/-}$mice with both mild and severe phenotype, showing that the phenotype heterogeneity was not due to differential transcription of the WT Scn5a allele. Ion channel remodeling in $S c n 5 a^{+/-}$mice was limited to 10 genes. Among them, 4 were moderately up-regulated in both groups of $\operatorname{Scn} 5 a^{+/-}$mice including ankyrin-B, an anchoring protein involved in ion channel (including $\mathrm{Na}_{\mathrm{v}} 1.5$ ) and transporter targeting [12,13]. Few genes were differentially regulated among the $S c n 5 a^{+/-}$mice. Five were up-regulated only in severely affected $S c n 5 a^{+/-}$mice, including genes encoding the $\mathrm{Na}^{+}$channel $\alpha$-subunit $\mathrm{Na}_{\mathrm{v}} 1.3$, the T-type $\mathrm{Ca}^{2+}$ channel $\alpha$-subunit $\mathrm{Ca}_{\mathrm{v}} 3.2$ and connexin 37. Finally, Kone1, which encodes KvLQT1 $\beta$-subunit, was up-regulated only in mice with mild phenotype. No gene expression (other than Scn5a) was
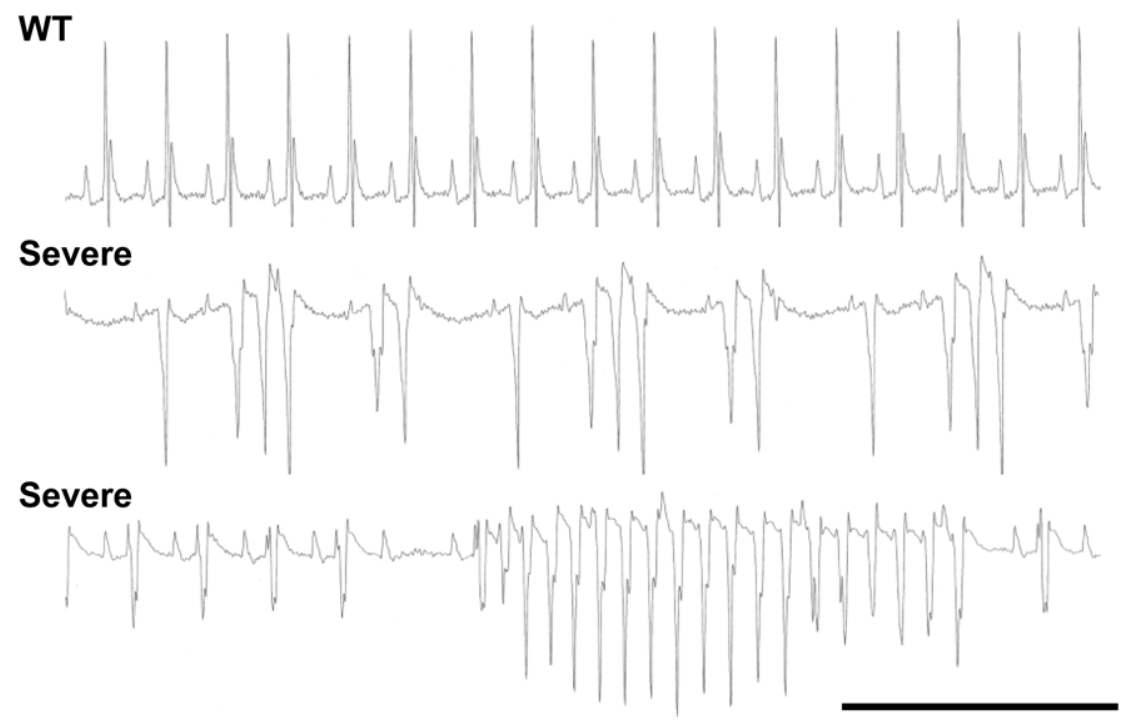

Figure 4. Cardiac arrhythmias in Scn5at+- mice with severe phenotype. Representative episodes of spontaneous ventricular arrhythmias recorded in two different $\mathrm{Scn} 5 \mathrm{a}^{+/-}$mice with a severe phenotype under anesthesia. An ECG recorded in an age-matched WT mouse is given for comparison. Scale bar, $500 \mathrm{~ms}$.

doi:10.1371/journal.pone.0009298.g004 
Table 2. ECG characteristics of asymptomatic $(n=84)$ and symptomatic $(n=24) S C N 5 A$-mutated Brugada patients.

\begin{tabular}{llllllll}
\hline & Age (yrs) & RR (ms) & P (ms) & PR (ms) & QRS (ms) & QT (ms) & QTc \\
\hline Asymptomatic & $41 \pm 2$ & $901 \pm 18$ & $93 \pm 3$ & $191 \pm 4$ & $110 \pm 2$ & $393 \pm 3$ & $417 \pm 3$ \\
Symptomatic & $46 \pm 3$ & $915 \pm 31$ & $97 \pm 4$ & $200 \pm 5^{*}$ & $118 \pm 4^{*}$ & $401 \pm 6$ & $417 \pm 7$ \\
\hline
\end{tabular}

Same abbreviations as in Table 1.

Data are mean \pm sem. ${ }^{*}, \mathrm{p}<0.05$ versus asymptomatic patients.

doi:10.1371/journal.pone.0009298.t002

significantly down-regulated. The expression of genes encoding pumps and exchangers was not altered.

\section{Reduced $\mathrm{Na}_{\mathrm{v}} 1.5$ Protein Expression and $\mathrm{I}_{\mathrm{Na}}$ Density in $\mathrm{Scn} 5 \mathrm{a}^{+/-}$Mice with a Severe Phenotype}

We then investigated $\mathrm{Na}_{\mathrm{v}} 1.5$ protein expression. Investigators were blinded to the genotype and phenotype for all the experiments presented below.

In young $S \mathrm{cn} 5 \mathrm{a}^{+/-}$mice, global $\mathrm{Na}_{\mathrm{v}} 1.5$ protein was reduced by $50 \pm 4 \%$ in ventricular lysates of animals with a severe phenotype versus WT littermates $(\mathrm{p}<0.001)$ and by only $21 \pm 7 \%$ for animals with a mild phenotype $(\mathrm{p}<0.05$ versus severe phenotype, NS versus WT; Figure 6).

At the single cell level, immunofluorescence and confocal imaging experiments demonstrated that $\mathrm{Na}_{\mathrm{v}} 1.5$ staining intensity in intercalated discs was reduced by $42 \pm 4 \%$ in myocytes from mice with severe phenotype (66 cells from 3 mice; $p<0.01$ versus WT), but only by $30 \pm 2 \%$ for mice with mild phenotype ( 60 cells from 3 mice; $\mathrm{p}<0.05$ versus severe, $\mathrm{p}<0.01$ versus $\mathrm{WT}$; Figure $6 \mathrm{C}$ ).

Accordingly, the $\mathrm{I}_{\mathrm{Na}}$ density was $28 \%$ larger in mice with a mild phenotype $(59 \pm 7 \mathrm{pA} / \mathrm{pF}$; 18 cells from 4 mice) than in mice with a severe phenotype ( $46 \pm 4 \mathrm{pA} / \mathrm{pF}$; 21 cells from 4 mice; Figure 7 ) although this difference did not reach significance $(p=0.08)$. For comparison, amplitude of $\mathrm{I}_{\mathrm{Na}}$ in WT mice was $103 \pm 7 \mathrm{pA} / \mathrm{pF}$ (16 cells from 4 mice). In summary, the three independent techniques indicated a less severe reduction of $\mathrm{Na}_{\mathrm{v}} 1.5$ proteins in mice with a mild phenotype than in mice with a severe phenotype. We also observed a shift towards more positive voltage values of steadystate inactivation and activation curves in $\operatorname{Scn} 5 a^{+/-}$mice versus WT mice (Table 3). However, no difference was observed among the $\operatorname{Scn} 5 a^{+/-}$mice.

The decrease in $\mathrm{I}_{\mathrm{Na}}$ induced a moderate (11-15\%) nonsignificant decrease in maximum upstroke velocity $\left(\mathrm{V}_{\max }\right)$ of ventricular action potentials in $S_{c n} 5 a^{+/-}$mice with mild conduction defects (Figure 8). In contrast, $\mathrm{V}_{\max }$ was significantly decreased by $33-42 \%$ in $\operatorname{Scn} 5 a^{+/-}$mice with a severe phenotype. They also exhibited a significant decrease in action potential amplitude. Other action potential parameters did not differ among the groups.

\section{Discussion}

The main findings of the present study are: (i) $\operatorname{Scn} 5 a^{+/-}$mice exhibit variable penetrance of the conduction deficit, as do patients with $S C N 5 A$ loss-of-function mutations $[2,6]$; (ii) $\operatorname{Scn} 5 a^{+/-}$mice with severe ventricular conduction defects, exhibit more myocardial rearrangements with aging than mice with a mild phenotype; (iii) only old mice with a severe phenotype have a markedly reduced conduction reserve and show spontaneous ventricular arrhythmias; (iv) symptomatic $\mathrm{BrS}$ patients carrying $S C N 5 A$ mutations have more pronounced conduction slowing than asymptomatic patients; and (v) the expressivity of the conduction deficit in $\operatorname{Scn} 5 a^{+/-}$mice is correlated with the expression level of WT functional $\mathrm{Na}_{\mathrm{v}} 1.5$ proteins. Mice with a severe phenotype correspond to the expected haploinsufficient situation since they exhibit $\approx 50 \%$ reduction in $\mathrm{Na}_{\mathrm{v}} 1.5$ protein expression whereas $\mathrm{Na}_{\mathrm{v}} 1.5$ reduction in mice with a mild phenotype was less pronounced.

Because distribution of QRS intervals in the $\operatorname{Scn} 5 a^{+/-}$mouse population is bimodal, we speculate that a compensatory mechanism is active in the mild-phenotype subgroup but inactive in the severe-phenotype subgroup. Such a mechanism governs the severity of the conduction slowing that in turn commands the extent of myocardial rearrangements and fibrosis, confirming our hypothesis of a direct link between ventricular conduction defects and fibrosis [10]. Moreover, that occurrence of large areas of fibrosis in mice with a severe phenotype was preceded by large overexpression of $\operatorname{Egr} 1$ and $A t f 3$ in these mice and not in mice with a mild phenotype, which have much less fibrosis, confirms our hypothesis that these transcription factors are involved in myocardial rearrangements [10].

\section{Molecular Mechanism for Variable Penetrance of the Phenotype in the Mouse}

Because cardiac conduction relies not only on $\mathrm{Na}^{+}$current, but also on cellular coupling and myocardial architecture, different hypotheses could be evoked to explain $\operatorname{S} c n 5 a^{+/-}$mice phenotypic variability. Variable myocardial rearrangement was not expected to explain phenotypic variability since heterogeneity is already present in young adult mice whereas fibrosis occurs only in older mice $[10,11]$. We first hypothesized that $\mathrm{Na}_{\mathrm{v}} 1.5$ invalidation could lead to altered expression of other ion channel subunits and of connexins that would vary among mice. Our data indicate that ion channel remodeling was limited to only a few genes. Among them, some were indeed differentially regulated depending on the phenotype severity. However, the contribution of these genes to the phenotype is unlikely since they are either not or weakly expressed in adult mouse ventricle. For instance, the cardiac expression of connexin-37 is restricted to endothelial cells [14]. Overexpression of the mRNA of neuronal $\mathrm{Na}^{+}$channel, $\mathrm{Na}_{\mathrm{v}} 1.3$, and T-type $\mathrm{Ca}^{2+}$ channel, $\mathrm{Ca}_{\mathrm{v}} 3.2$, may result from a feedback mechanism compensating for the larger conduction deficit of mice with a severe phenotype. In any case, the putative resulting increase in $\mathrm{Na}^{+}$and T-type $\mathrm{Ca}^{2+}$ currents would improve conduction and not further deteriorate it. The consequences of KvLQT1 $\beta$-subunit (Kcne1 gene) overexpression in $S c n 5 a^{+/-}$mice with a mild phenotype are also difficult to predict. In adult mice, Kcne1 cardiac expression is restricted to the conduction system [15]. Based on studies performed on Langendorff-perfused hearts showing that targeted disruption of Kcnel can alter ventricular conduction velocity [16], one could speculate that Kcne1 overexpression in $S_{c n} 5 a^{+/-}$mice with a mild phenotype could contribute to their shorter QRS interval. However EGG recordings in Kcne1 knockout mice did not display any alteration of the QRS interval [15], suggesting that this protein is not playing a major role in cardiac impulse propagation. 

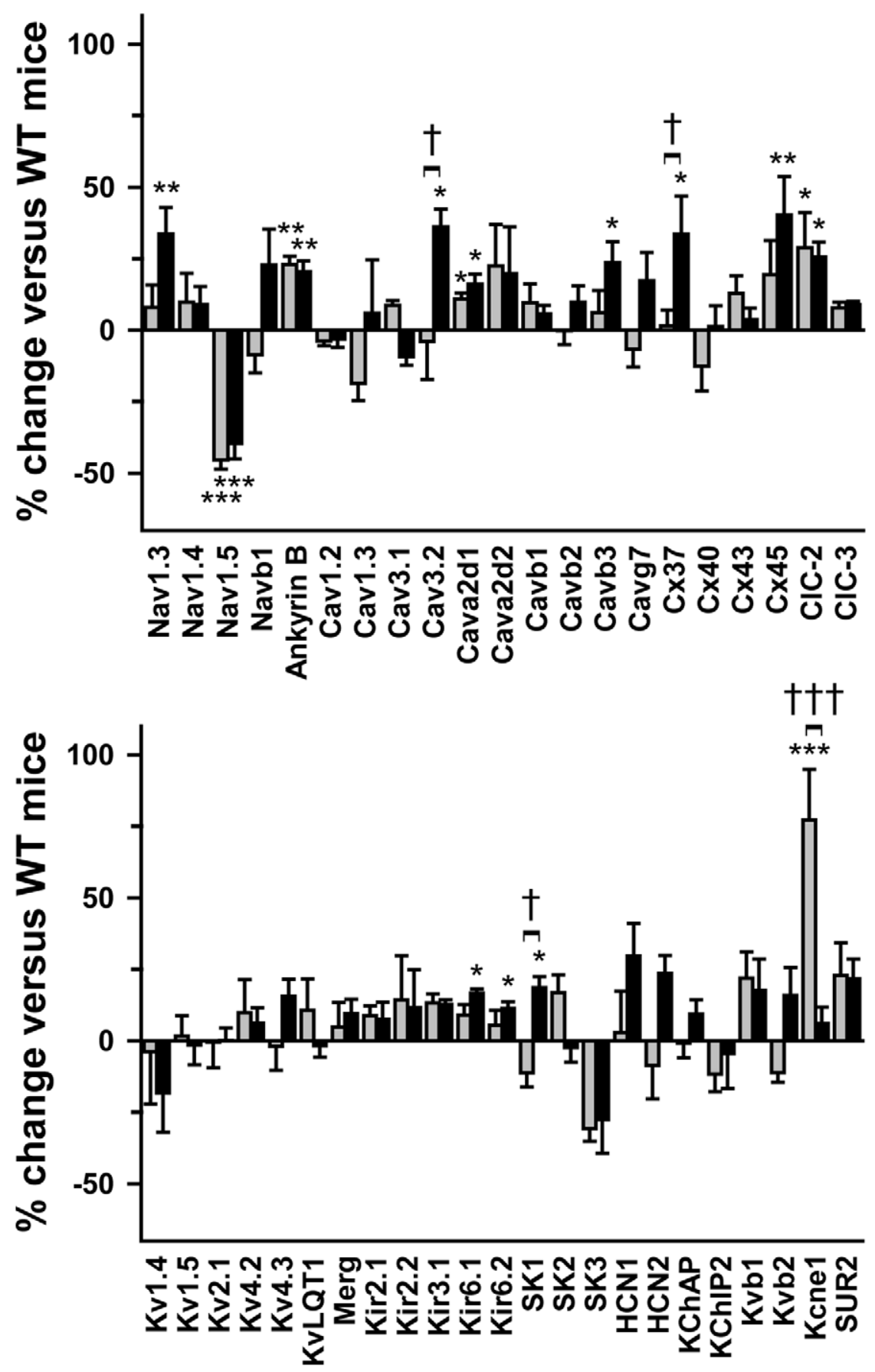

Figure 5. Moderate ionic remodeling in $S c n 5 a^{+/-}$mice. Percentage of variation in ventricular expression ( $\mathrm{Y}$-axes) of 46 genes encoding ion channel subunits (ch) and connexins $(\mathrm{Cx})$ in $\mathrm{Scn} 5 \mathrm{a}^{+/-}$mice with mild (grey bars; $\mathrm{n}=5$ ) and severe (black bars; $\mathrm{n}=7$ ) phenotype versus WT mice $(n=10)$. Sub, subunits. ${ }^{*}, * * * *, p<0.05, p<0.01$ and $p<0.001$ respectively versus $W_{T} ;, \dagger \dagger \dagger, p<0.05$ and $p<0.001$ respectively versus mild phenotype.

doi:10.1371/journal.pone.0009298.g005

An alternative hypothesis for explaining phenotypic variability was that $\operatorname{Scn} 5 a^{+/-}$mice had variable reduction in $\mathrm{Na}^{+}$current. Scn5a transcript levels were similar in both groups of $S_{c n} 5 a^{+/-}$ mice suggesting the same transcriptional regulation of the WT. However, $\mathrm{Na}_{\mathrm{v}} 1.5$ protein amounts and $\mathrm{I}_{\mathrm{Na}}$ were larger in $\operatorname{Scn} 5 a^{+/-}$ mice with a mild phenotype. The reason for increased expression of $\mathrm{Na}_{\mathrm{v}} 1.5$ protein in mice with a mild phenotype is as yet unknown. In addition to gene transcription and RNA processing, the expression of functional $\mathrm{Na}_{\mathrm{v}} 1.5$ proteins will depend on a series of complex interacting processes such as protein synthesis, assembly and post-translational modifications, trafficking to the sarcolemma, anchoring to the cytoskeleton and regulation of endocytosis and degradation, which are yet incompletely understood $[17,18]$.

At first glance, QRS variability might appear unexpectedly large for an inbred mouse strain. It is widely recognized that environmental, investigator-dependent, and time variables can be confounding factors influencing the characterization of mouse 
A

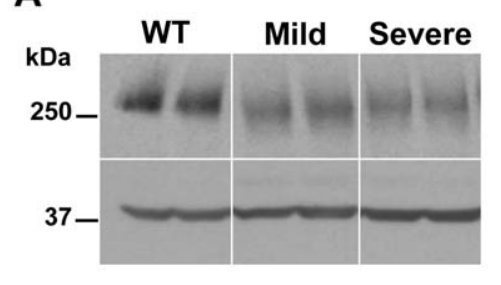

C

WT

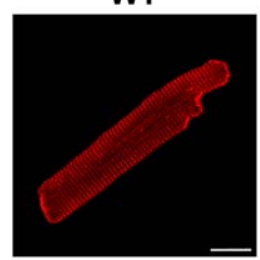

Mild

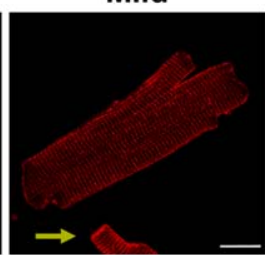

B

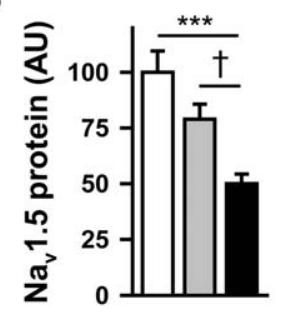

Severe

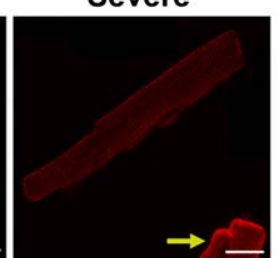

Figure 6. Decreased $\mathrm{Na}_{\mathrm{v}} \mathbf{1 . 5}$ expression in $\mathrm{Scn} 5 \mathrm{a}^{+/-}$mice. A. Representative Western blots showing the expression levels of $\mathrm{Na}_{\mathrm{v}} 1.5$ in WT mice and $\mathrm{Scn} 5 \mathrm{a}^{+-}$mice (mean age $=18 \pm 1$ weeks) with a mild or a severe phenotype. Protein loading was controlled by anti-actin immunoblotting. B. Quantification of $\mathrm{Na}_{\mathrm{v}} 1.5$ expression in WT mice (open bars) and Scn5a $a^{+/-}$mice with mild (grey bars) and severe (black bars) phenotype was performed on Western blots from 10 mice in each group by normalizing the intensities of the $\mathrm{Na}_{\mathrm{v}} 1.5$ bands to the actin bands. ${ }^{* * *}, \mathrm{p}<0.001$ versus WT; $\uparrow, \mathrm{p}<0.05$ versus mild $\operatorname{Scn} 5 a^{+-}$mice. $\mathbf{C}$. Confocal images of $\mathrm{Na}_{\mathrm{v}} 1.5$ in ventricular cardiomyocytes isolated from WT mice (left panel) and $S \mathrm{Cn} 5 \mathrm{a}^{+/-}$mice with mild (middle panel) and severe (right panel) phenotype. Scale bar, $20 \mu \mathrm{m}$. In Scn5a ${ }^{+/-}$images presented, a WT cardiomyocyte is also included in the image frame (yellow arrows) to illustrate the clear difference in WT versus Scn5a $a^{+-}$ intercalated disc staining intensities.

doi:10.1371/journal.pone.0009298.g006

phenotypes $[19,20]$. However, some of these variables are unlikely to explain phenotypic variability of $\operatorname{Scn} 5 a^{+/-}$mice. Indeed, a single investigator carried out all ECG recordings and analyses. Moreover, since long-term follow-up studies have shown that the mice keep their phenotype severity throughout their life, possible interference with the season or time of the day can be excluded. Finally, and perhaps more importantly, histological studies, immunoblot experiments, patch-clamp and microelectrode recordings were performed under blind conditions.

In both groups of $S_{c n} 5 a^{+/-}$mice, the steady-state inactivation and activation and curves were shifted towards more positive voltages than in wild-type mice. To our knowledge, this phenomenon has not described before. It may be speculated that a decrease in the number of sarcolemmal $\mathrm{Na}^{+}$channels could trigger changes in the expression/interaction of proteins that remain to be indentified altering $\mathrm{Na}_{\mathrm{v}} 1.5$ biophysical properties. Whatever its mechanism, one consequence of this shift should be that the fraction of $\mathrm{Na}^{+}$channels available for cardiac depolarization is larger in $\operatorname{Scn} 5 a^{+/-}$mice (about 80\%) than in wild-type mice $(50 \%)$.

Potential Implications in PCCD and Brugada Syndrome

We are not aware of long-term individual follow-up data in patients with PCCD that would extend over decades. Comparison between mice and humans is thus difficult to achieve. Our study points to a key similarity between $\operatorname{Scn} 5 a^{+/-}$mice and loss-offunction $S C N 5 A$ mutation human carriers. Young $\operatorname{Scn} 5 a^{+/-}$mice or patients with markedly prolonged QRS interval have a conduction reserve similar to $S c n 5 a^{+/-}$mice or patients with mildly prolonged QRS interval, but this reserve fades out with
A
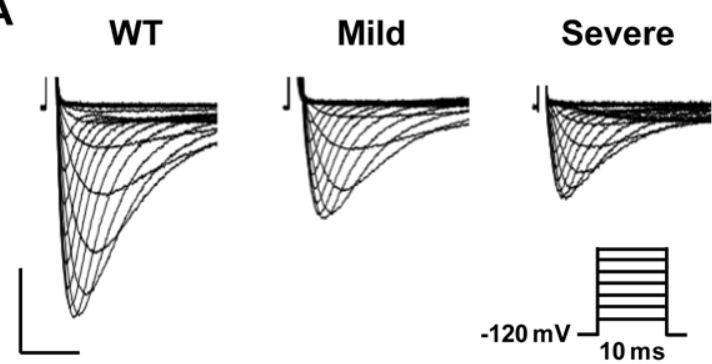

B

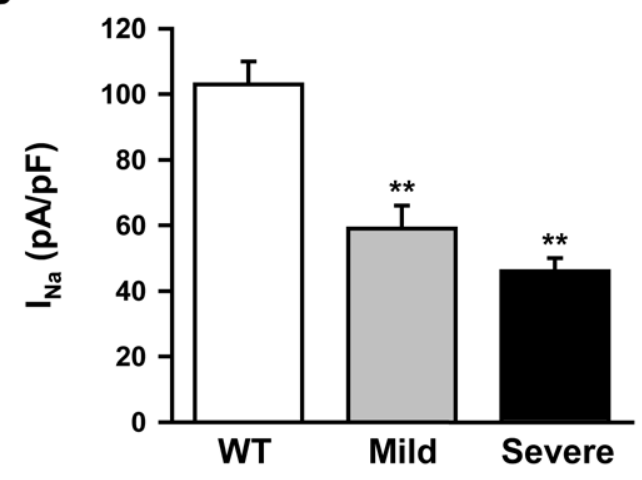

Figure 7. Variable $I_{\mathrm{Na}}$ densities in $S \mathrm{Cn} 5 \mathrm{a}^{+/-}$single ventricular cardiomyocytes. A. Representative $I_{\mathrm{Na}}$ traces (protocol in inset) obtained from ventricular myocytes in a 12 week-old WT mouse and $\mathrm{Scn} 5 \mathrm{a}^{+/-}$mice with mild and severe phenotype. Horizontal bar, $2 \mathrm{~ms}$; vertical bar, $40 \mathrm{pA} / \mathrm{pF}$. B. $\mathrm{I}_{\mathrm{Na}}$ density in myocytes from WT and $\mathrm{Scn} 5 \mathrm{a}^{+/-}$ mice with mild and severe phenotype (4 mice in each group, 4 to 6 cells for each mouse). ${ }^{* *}, p<0.01$ versus WT mice. doi:10.1371/journal.pone.0009298.g007

aging. If findings obtained in mouse can be transposed in human, they suggest that depending on the duration of the QRS complex at young age, one may predict the evolution of the conduction disease and requirement for pacemaker in patients with inherited PCGD. Interestingly, in families with $S C N 5 A$-related PCCD, the phenotype heterogeneity is high at middle age and some old mutated patients do not develop the disease [2]. In $S_{\mathrm{cn} 5 a^{+/-}}$ mouse, decreased conduction reserve is due to fibrosis and connexin expression remodeling [10,11], which can be considered

Table 3. $I_{\mathrm{Na}}$ steady-state activation and inactivation properties of isolated ventricular myocytes from wild-type (WT) and Scn5a $a^{+/-}$mice with mild and severe phenotype.

\begin{tabular}{llll}
\hline & WT & Mild Scn5a ${ }^{+/-}$ & Severe Scn5a ${ }^{+/-}$ \\
\hline Activation & $\mathrm{n}=12$ & $\mathrm{n}=13$ & $\mathrm{n}=10$ \\
\hline $\mathbf{K}$ (mV/e-fold) & $5.9 \pm 0.1$ & $6.1 \pm 0.2$ & $5.9 \pm 0.1$ \\
$\mathbf{V}_{\mathbf{1 / 2}}$ (mV) & $-37.6 \pm 1.0$ & $-31.2 \pm 2.0^{*}$ & $-31.0 \pm 1.3^{*}$ \\
Inactivation & $\mathrm{n}=10$ & $\mathrm{n}=10$ & $\mathrm{n}=10$ \\
\hline $\mathbf{K}$ (mV/e-fold) & $6.4 \pm 0.2$ & $6.8 \pm 0.3$ & $7.0 \pm 0.2$ \\
$\mathbf{V}_{\mathbf{1 / 2}}$ (mV) & $-77.9 \pm 2.5$ & $-68.8 \pm 2.5^{*}$ & $-68.0 \pm 1.6^{* *}$ \\
\hline
\end{tabular}

Abbreviations are: $n$, number of myocytes per group; $K$, slope factor; $V_{1 / 2}$, halfactivation or half-inactivation voltage (see methods section for calculation procedure).

Data are mean \pm sem. ${ }^{*},{ }^{* *}, p<0.05$ and $p<0.01$ respectively versus WT (Kruskal-Wallis test, Dunn's post-test).

doi:10.1371/journal.pone.0009298.t003 

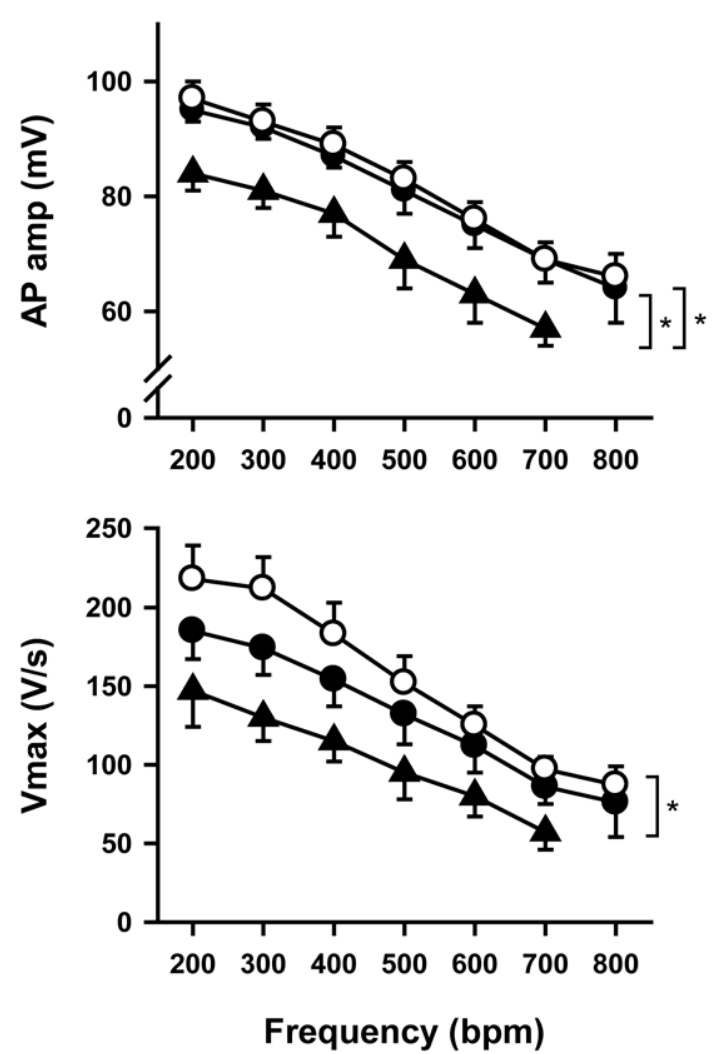

Figure 8. Action potential amplitude (AP amp; top) and maximum upstroke velocity (Vmax; bottom) as a function of pacing frequency. White circles, wild type mice $(n=7)$; black circles, $\operatorname{Scn} 5 a^{+--}$mice with a mild phenotype $(\mathrm{n}=6)$; black triangles, $\operatorname{Scn} 5 \mathrm{a}^{+--}$ mice with a severe phenotype $(n=5)$. At $800 \mathrm{bpm}, 4$ preparations from $\mathrm{Scn} 5 \mathrm{a}^{+/-}$mice with a severe phenotype were periodically (for 1 of them) or continuously (for the 3 others) in 2:1 conduction block. ${ }^{*}, \mathrm{p}<0.05$. doi:10.1371/journal.pone.0009298.g008

as possible therapeutic targets to limit the evolution of the disease. However, even if mice and humans present similar phenotypes, this does not imply that the same pathophysiological mechanisms are involved.

In old $S_{c n} 5 a^{+/-}$mice with severe phenotype, fibrosis and connexin expression remodeling could partly explain the high incidence of spontaneous ventricular arrhythmias, which were never observed in mice with a mild phenotype and WT mice. Indeed, the presence of large areas of fibrosis associated with connexin-43 redistribution in areas surrounding fibrosis [11] most likely contributes to the occurrence of reentrant arrhythmias. We never observed any arrhythmias in younger animals, although $e x$ vivo experiments had shown that young adult $\operatorname{Scn} 5 a^{+/-}$mice were more prone than WT mice to develop arrhythmias under programmed electrical stimulation [9]. This suggests that the decrease in $\mathrm{I}_{\mathrm{Na}}$ per se is not enough to trigger spontaneous arrhythmias in mice.

In our cohort, symptomatic SCN5A-related BrS patients were characterized by more pronounced ventricular conduction defects than asymptomatic patients. This confirms a recent publication by Junttila and co-workers [21] and supports further the importance of conduction defects in Brugada syndrome pathophysiology $[22,23]$. Whether the substrate for arrhythmias in SCN5A-related $\mathrm{BrS}$ patients relies essentially on $\mathrm{Na}_{\mathrm{v}} 1.5$ dysfunction or involves additional myocardial rearrangements is unclear. Although structural abnormalities are not detected using routine noninvasive diagnostic tools, fatty replacement, right ventricular fibrosis, myocyte degeneration and apoptosis have been reported [23-25]. Moreover, a boy with compound heterozygosity for two SCN5A mutations exhibited severe degenerative changes in the ventricular conduction system [26]. Taken together, studies in patients and in $\operatorname{Scn} 5 a^{+/-}$mice strongly suggest that a primary abnormality in $\mathrm{Na}_{\mathrm{v}} 1.5$ channel may lead to cellular damage. On this basis, arrhythmias may occur when a sufficient degree of myocardial rearrangement has been reached. This would explain why, in the context of an inborn defect, several years (in humans) or months (in mice) might elapse before the first arrhythmic event.

\section{Materials and Methods}

\section{Ethics Statement}

All the animal experiments were performed in the animal facility (Unité de Thérapeutique Expérimentale) and the Inserm UMR915 laboratory which have been accredited by the French Ministry of Agriculture. Experimental procedures were approved by the regional ethic committee (CREEA - Pays de la Loire).

Studies involving human participants were conducted according to the French and Dutch guidelines for genetic research. All tests that were performed were approved by the medical ethical review committees of the two hospitals involved: Academic Medical Center, Amsterdam, The Netherlands; Centre Hospitalo-Universitaire, Nantes, France (CCPPRB des Pays de la Loire). Written informed consent was obtained from the patients.

\section{Electrocardiography in Mouse}

All mice with 129/Sv genetic background were bred at l'institut $d u$ thorax (Nantes, France) and genotyped by polymerase chain reaction (PGR) as previously described [9]. All experiments were performed on age-matched wild-type (WT) and heterozygous littermates.

Six-lead ECGs were recorded on mice anesthetized with etomidate $(25 \mathrm{mg} / \mathrm{kg}$ i.p.) and analyzed as previously described [10]. Pharmacological challenge with the $\mathrm{Na}^{+}$channel blocker ajmaline $(20 \mathrm{mg} / \mathrm{kg}$, i.p.) was performed in 10 and $>53$ week-old mice. QRS interval lengthening was assessed 10 minutes after injection.

\section{ECG Recordings and Clinical Data from Patients with SCN5A Mutations}

The study was conducted according to the French and Dutch guidelines for genetic research. All tests that were performed were approved by the medical ethical review committees of the two hospitals involved: Academic Medical Center, Amsterdam, The Netherlands; Centre Hospitalo-Universitaire, Nantes, France (CCPPRB des Pays de la Loire). Written informed consent was obtained from the patients.

A first study was aimed at evaluating the effects of ajmalin on conduction defects in patients from the Nantes database carrying SCN5A loss-of-function mutations. The cohort included families with SCN5A mutations leading to Brugada syndrome only and families with $S C N 5 A$ mutations leading to either progressive cardiac conduction defects (PCCD) or Brugada syndrome [27]. These patients had a median QRS interval duration of $108 \pm 12 \mathrm{~ms}$. This value was used as a cut-off to discriminate patients with minor conduction defects $(\mathrm{QRS} \leq 108 \mathrm{~ms}$; mild phenotype) or major conduction defects (QRS>108 ms; severe phenotype). Non-mutation carrier siblings served as controls. Two age groups were then distinguished, 6-31 years and 41-61 years. In the 6-31 year-old patient group (mean value: $21 \pm 2$ years; $\mathrm{n}=19$ ), patients with a mild phenotype had a mean QRS duration 
of $98 \pm 3 \mathrm{~ms} \quad(80-108 \mathrm{~ms} ; \mathrm{n}=12)$ and those with a severe phenotype had a mean QRS duration of $130 \pm 7 \mathrm{~ms}$ (110$158 \mathrm{~ms} ; \mathrm{n}=7 ; \mathrm{p}<0.001$ versus mild). In the older patient group (51 \pm 1 years; $n=23$ ), patients with a mild phenotype had a mean QRS interval of $94 \pm 2 \mathrm{~ms}(80-107 \mathrm{~ms} ; \mathrm{n}=11)$ whereas patients with a severe phenotype had a QRS of $122 \pm 4 \mathrm{~ms}(112-160 \mathrm{~ms}$; $\mathrm{n}=12 ; \mathrm{p}<0.001$ versus mild). All patients were challenged with ajmaline according to current guidelines [28].

In a second study, clinical data from patients carrying $S C N 5 A$ mutations leading to Brugada syndrome from the Nantes and Amsterdam databases were pooled $(n=108)$. This mixed database was used to discriminate symptomatic and asymptomatic patients. Symptomatic patients had a clinical history of collapses, syncopes, documented ventricular tachycardia (and/or fibrillation) or aborted sudden death. Baseline QRS interval duration were compared between symptomatic and asymptomatic patients.

\section{Histology}

Cardiac arrest was induced in sedated mice (etomidate, $30 \mathrm{mg}$ / $\mathrm{kg}$ i.p.) with intravenous infusion of $10 \% \mathrm{KCl}$. After excision, hearts were rinsed in saline solution and fixed by immersion in $10 \%$ formalin for $24 \mathrm{~h}$. Then, gross transverse sections were cut from the base to the apex and embedded in paraffin. Paraffin sections were stained with hematoxylin-eosin to assess any myocyte necrosis or interstitial inflammation or Sirius red to assess interstitial and scar fibrosis. Serial sections were cut to track the ventricular outflow tract. Semi-quantitative assessment of fibrosis was determined based upon the extent and the number of interstitial fibrosis and scar foci (and scored 0 to 3).

\section{TaqMan Real-Time RT-PCR}

For Atf3 and Egrl genes, Taqman real-time RT-PCR was performed as previously described [10]. The ion channel gene expression patterns of ventricular preparations from WT and $S_{c n} 5 a^{+/-}$mice were characterized with TaqMan Low Density Arrays (Applied Biosystems, Foster City, CA) in a two-step RTPCR process. The genes selected for their cardiac expression encode 68 ion channel $\alpha$ - and auxiliary subunits, 7 proteins involved in calcium homeostasis, 5 transcription factors, specific markers of cardiac regions, vascular vessels, neuronal tissue, fibroblasts, inflammation and hypertrophy, and 4 endogenous control genes used for normalization. First strand cDNA was synthesized from $220 \mathrm{ng}$ of total RNA using the High-Capacity cDNA Archive Kit (Applied Biosystems). Experimental procedure and data analysis were performed as previously described [29].

\section{Protein Isolation and Western Blot}

After excision, hearts were rapidly frozen in liquid nitrogen and stored at $-80^{\circ} \mathrm{C}$. Frozen mouse ventricle was transferred into lysis buffer containing (in mmol/L): trishydroxyaminomethane (TRIS), 50 (pH 7.5); NaCl, 150; ethylenediaminetetra-acetic acid (EDTA), 1 ; phenylmethylsulfonyl fluoride (PMSF), 1; Complete ${ }^{\circledR}$ protease inhibitor cocktail from Roche Applied Science (Basel, Switzerland). Tissues were then homogenized using a Polytron. Triton Tx-100 was added to a final concentration of $1 \%$ and solubilization occurred by rotating for $1 \mathrm{~h}$ at $4^{\circ} \mathrm{C}$. The soluble fraction from a subsequent 15-min centrifugation at $13,000 \mathrm{~g}$ $\left(4^{\circ} \mathrm{C}\right)$ was used for the experiments. In order to load each lane of the SDS-page with equivalent amounts of total proteins, the protein concentration of each lysate was measured in triplicate by Bradford assay using a BSA standard curve.

Polyclonal anti-Na $\mathrm{N}_{\mathrm{v}} 1.5$ antibody (ASC-005) was purchased from Alomone (Jerusalem, Israel) and rabbit anti-actin antibody (A 2066) was purchased from Sigma (Buchs, Switzerland). The immunoblot signals were visualized using enhanced chemiluminescence (ECL). Densitometric analyses of ECL films were performed using QuantityOne Software (BioRad, Hercules, California, USA). Bands were manually selected using the volume tool. For each band, the background was subtracted and the signal intensity was normalized to actin.

\section{Immunofluorescence Experiments on Isolated Cardiomyocytes}

Cardiomyocytes were washed with phosphate-buffered saline (PBS, $\mathrm{pH} 7.4)$ and fixed in $2 \%$ paraformaldehyde $\left(37^{\circ} \mathrm{C}\right)$. Cells were blocked/permeabilized in PBS containing $0.075 \%$ Triton X-100 and $3 \%$ fish oil gelatin, and incubated in primary antibody, (polyclonal $\mathrm{Na}_{\mathrm{v}} 1.5$ antibody) overnight at $4^{\circ} \mathrm{C}$ [30]. Following washes (PBS plus $0.1 \%$ Triton $\mathrm{X}-100$ ), cells were incubated in secondary antibody (Alexa 568; Molecular Probes) for 8 hours at $4^{\circ} \mathrm{C}$ and mounted using Vectashield (Vector). Images were collected on a Zeiss 510 Meta confocal microscope (63 power oil immersion, 1.4 NA, 1.0 Airy Units) using Carl Zeiss Imaging software. Volocity Classification and LSM510 software (Zeiss) were used to measure pixel intensities. The following imaging protocol was adopted. Data were first collected on WT cardiomyocytes to establish a linear imaging protocol. All cardiomyocytes were imaged using an identical imaging protocol (LSM510 're-use' function to ensure consistency in pinhole diameter, brightness, contrast, and laser intensity). Since $\mathrm{Na}_{\mathrm{v}} 1.5$ is primarily expressed in the intercalated disc region [31,32], we determined the mean staining intensity for 3 intercalated disc line scans per myocyte. For each group, at least 60 myocytes from 3 different mice were analyzed.

\section{Isolation of Cardiac Myocytes and Patch Clamp Experiments}

Ventricular myocytes were isolated as previously described [33]. Whole-cell configuration of the patch-clamp technique was used to record $\mathrm{I}_{\mathrm{Na}}$. Experiments were performed at room temperature $\left(22-23^{\circ} \mathrm{C}\right.$ ), using a VE-2 (Alembic Instruments, Canada) amplifier allowing the recording of large $\mathrm{Na}^{+}$currents. Pipettes (tip resistance of 1-2 M $\Omega$ ) were filled with a solution containing (in mmol/L): CsCl, 60; Cesium asparte, 70; $\mathrm{CaCl}_{2}, 1 ; \mathrm{MgCl}_{2}, 1$; HEPES, 10; EGTA, 11; $\mathrm{Na}_{2} \mathrm{ATP}, 5$ (pH was adjusted to 7.2 with $\mathrm{CsOH}$ ). Myocytes were bathed with a solution containing (in mmol/L): NaCl, 10; NMDG-Cl, 120; $\mathrm{CaCl}_{2}, 2 ; \mathrm{MgCl}_{2}$, 1.2; CsCl, 5; HEPES, 10; Glucose 5 ( $\mathrm{pH}$ was adjusted to 7.4 with $\mathrm{CsOH}$ ). Holding potentials were $-120 \mathrm{mV}$ and $\mathrm{I}_{\mathrm{Na}}$ densities $(\mathrm{pA} / \mathrm{pF})$ were obtained by dividing the peak $\mathrm{I}_{\mathrm{Na}}$ by the cell capacitance. Peak currents were measured during a voltage-clamp protocol.

To quantify the voltage dependence of steady-state activation and inactivation, data from individual cells were fitted with the Boltzmann relationship, $\mathrm{y}\left(\mathrm{V}_{\mathrm{m}}\right)=1 / 1+\exp \left[\left(\mathrm{V}_{\mathrm{m}}-\mathrm{V}\right) / \mathrm{K}\right]$, in which $\mathrm{y}$ is the normalized current or conductance, $\mathrm{V}$ is the voltage at which half of the available channels are inactivated, $\mathrm{K}$ is the slope factor, and $\mathrm{V}_{\mathrm{m}}$ is the membrane potential. The voltage dependence of inactivation was determined by measuring current in response to pulses $(20 \mathrm{~ms})$ to $-20 \mathrm{mV}$ that had been preceded by $500-\mathrm{ms}$ pulses applied in a series of $5-\mathrm{mV}$ incremental voltages from $-130 \mathrm{mV}$ to $-20 \mathrm{mV}$.

\section{Microelectrode Studies}

Seven wild-type (WT) and 11 Scn5a $a^{+/-}$(6 with a mild phenotype and 5 with a severe phenotype) adult mice of either sex were killed by cervical dislocation. The hearts were quickly removed and immersed in a cool modified Tyrode solution containing (in mmol/L): NaCl, 108; $\mathrm{NaHCO}_{3}, 25 ; \mathrm{NaH}_{2} \mathrm{PO}_{4}, 1.8 ; \mathrm{KCl}, 27$; 
$\mathrm{MgCl}_{2}, 1 ; \mathrm{CaCl}_{2}, 0.6$; glucose, 55 and previously saturated with a $95 \% \quad \mathrm{O}_{2}-5 \% \quad \mathrm{CO}_{2}$ gas mixture $(\mathrm{pH}$ 7.3). Preparations were mounted in a tissue bath chamber, the endocardial surface facing up and superfused with an oxygenated $\left(95 \% \mathrm{O}_{2}-5 \% \mathrm{CO}_{2}\right)$ Tyrode solution warmed to $37 \pm 0.5^{\circ} \mathrm{C}$ and containing (in mmol/L): $\mathrm{NaCl}$, 120; $\mathrm{NaHCO}_{3}, 27 ; \mathrm{NaH}_{2} \mathrm{PO}_{4}, 1.2 ; \mathrm{KCl}, 5.4 ; \mathrm{MgCl}_{2}, 1.2 ; \mathrm{CaCl}_{2}$, 1.8; glucose, 10 (pH 7.4). Transmembrane recordings were obtained using standard methods. The tissues were allowed to recover for at least one hour before the experiments started. During this period, they were paced at a frequency of 300 beat per minute (bpm) by bipolar stimulation through Teflon-coated silver wire electrodes. Stimulus pulse width was $1 \mathrm{~ms}$ and amplitude was twice diastolic threshold. The preparations were then paced at frequencies increasing from 200 to $800 \mathrm{bpm}$. Action potentials characteristics were measured at steady state for each frequency.

\section{Statistical Analysis}

Data are expressed as mean \pm SEM. Statistical analysis was performed with Student $t$-test, Kruskall-Wallis test and one- or

\section{References}

1. Schott J-J, Alshinawi C, Kyndt F, Probst V, Hoorntje TM, et al. (1999) Cardiac conduction defects associate with mutations in SCN5A. Nat Genet 23: 20-21.

2. Probst V, Kyndt F, Potet F, Trochu J-N, Mialet G, et al. (2003) Haploinsufficiency in combination with aging causes SCN5A-linked hereditary Lenegre disease. J Am Coll Cardiol 41: 643-652.

3. Chen Q, Kirsch GE, Zhang D, Brugada R, Brugada J, et al. (1998) Genetic basis and molecular mechanism for idiopathic ventricular fibrillation. Nature 392: 293-296.

4. Tan HL, Bezzina CR, Smits JP, Verkerk AO, Wilde AA (2003) Genetic control of sodium channel function. Cardiovasc Res 57: 961-973.

5. Clancy CE, Kass RS (2002) Defective cardiac ion channels: from mutations to clinical syndromes. J Clin Invest 110: 1075-1077.

6. Smits JP, Eckardt L, Probst V, Bezzina CR, Schott J-J, et al. (2002) Genotypephenotype relationship in Brugada syndrome: electrocardiographic features differentiate SCN5A-related patients from non-SCN5A-related patients. J Am Coll Cardiol 40: 350-356.

7. Probst V, Allouis M, Sacher F, Pattier S, Babuty D, et al. (2006) Progressive cardiac conduction defect is the prevailing phenotype in carriers of a Brugada syndrome SCN5A mutation. J Cardiovasc Electrophysiol 17: 270-275.

8. Kaab S, Schulze-Bahr E (2005) Susceptibility genes and modifiers for cardiac arrhythmias. Cardiovasc Res 67: 397-413.

9. Papadatos GA, Wallerstein PM, Head CE, Ratcliff R, Brady PA, et al. (2002) Slowed conduction and ventricular tachycardia after targeted disruption of the cardiac sodium channel gene Scn5a. Proc Natl Acad Sci USA 99: 6210-6215.

10. Royer A, van Veen TA, Le Bouter S, Marionneau C, Griol-Charhbili V, et al. (2005) Mouse model of SCN5A-linked hereditary Lenegre's disease: age-related conduction slowing and myocardial fibrosis. Circulation 111: 1738-1746.

11. van Veen TA, Stein M, Royer A, Le Quang K, Charpentier F, et al. (2005) Impaired impulse propagation in Scn5a-knockout mice: combined contribution of excitability, connexin expression, and tissue architecture in relation to aging. Circulation 112: 1927-1935.

12. Mohler PJ, Schott J-J, Gramolini AO, Dilly KW, Guatimosim S, et al. (2003) Ankyrin-B mutation causes type 4 long-QT cardiac arrhythmia and sudden cardiac death. Nature 421: 634-639.

13. Chauhan VS, Tuvia S, Buhusi M, Bennett V, Grant AO (2000) Abnormal cardiac $\mathrm{Na}(+)$ channel properties and QT heart rate adaptation in neonatal ankyrin(B) knockout mice. Circ Res 86: 441-447.

14. van Veen TA, van Rijen HV, Jongsma HJ (2006) Physiology of cardiovascular gap junctions. Adv Cardiol 42: 18-40.

15. Kupershmidt S, Yang T, Anderson ME, Wessels A, Niswender KD, et al. (1999) Replacement by homologous recombination of the $\operatorname{minK}$ gene with lac $Z$ reveals restriction of $\operatorname{minK}$ expression to the mouse cardiac conduction system. Circ Res 84: $146-152$.

16. Balasubramaniam R, Grace AA, Saumarez RC, Vandenberg JI, Huang CL (2003) Electrogram prolongation and nifedipine-suppressible ventricular arrhythmias in mice following targeted disruption of KCNE1. J Physiol 552: 535-546.

17. Herfst LJ, Rook MB, Jongsma HJ (2004) Trafficking and functional expression of cardiac Na+ channels. J Mol Cell Cardiol 36: 185-193. two-way analysis of variance completed by a Tukey test when appropriate. The Fisher Exact test was used for the statistical analysis of proportions of mice with arrhythmias. A value of $\mathrm{p}<0.05$ was considered significant.

\section{Acknowledgments}

The authors wish to thank Béatrice Leray (Inserm UMR915), Agnès Carcouet (Inserm UMR915), Romuald Gilier (Inserm UMR915) and Martine Douheret (Inserm U652) for expert technical assistance and Dr Connie R Bezzina for critical reading of the manuscript and helpful discussion.

\section{Author Contributions}

Conceived and designed the experiments: VP JJS SD PB CLH WHC AAG HLM AW PJM DE HA FC. Performed the experiments: ALL BG JSR CM VP SLS PB AW PJM FC. Analyzed the data: ALL BG JSR CM VP SLS JJS SD PB HLM AW PJM DE HA FC. Contributed reagents/ materials/analysis tools: CLH WHC AAG. Wrote the paper: ALL HA FC.

18. Abriel H, Kass RS (2005) Regulation of the voltage-gated cardiac sodium channel Nav1.5 by interacting proteins. Trends Cardiovasc Med 15: 35-40.

19. Champy MF, Selloum M, Piard L, Zeitler V, Caradec C, et al. (2004) Mouse functional genomics requires standardization of mouse handling and housing conditions. Mamm Genome 15: 768-783.

20. Chesler EJ, Wilson SG, Lariviere WR, Rodriguez-Zas SL, Mogil JS (2002) Influences of laboratory environment on behavior. Nat Neurosci 5: 1101-1102.

21. Junttila MJ, Brugada P, Hong K, Lizotte E, De Zutter M, et al. (2008) Differences in 12-lead electrocardiogram between symptomatic and asymptomatic Brugada syndrome patients. J Cardiovasc Electrophysiol 19: 380-383.

22. Tukkie R, Sogaard P, Vleugels J, de Groot IK, Wilde AA, et al. (2004) Delay in right ventricular activation contributes to Brugada syndrome. Circulation 109: 1272-1277.

23. Meregalli PG, Wilde AA, Tan HL (2005) Pathophysiological mechanisms of Brugada syndrome: depolarization disorder, repolarization disorder, or more? Cardiovasc Res 67: 367-378.

24. Frustaci A, Priori SG, Pieroni M, Chimenti C, Napolitano G, et al. (2005) Cardiac histological substrate in patients with clinical phenotype of Brugada syndrome. Circulation 112: 3680-3687.

25. Coronel R, Casini S, Koopmann TT, Wilms-Schopman FJ, Verkerk AO, et al. (2005) Right ventricular fibrosis and conduction delay in a patient with clinical signs of Brugada syndrome: a combined electrophysiological, genetic, histopathologic, and computational study. Circulation 112: 2769-2777.

26. Bezzina CR, Rook MB, Groenewegen WA, Herfst LJ, van der Wal AC, et al. (2003) Compound heterozygosity for mutations (W156X and R225W) in SCN5A associated with severe cardiac conduction disturbances and degenerative changes in the conduction system. Circ Res 92: 159-168.

27. Kyndt F, Probst V, Potet F, Demolombe S, Chevallier J-C, et al. (2001) Novel SCN5A mutation leading either to isolated cardiac conduction defect or Brugada syndrome in a large French family. Circulation 104: 3081-3086.

28. Antzelevitch C, Brugada P, Borggrefe M, Brugada J, Brugada R, et al. (2005) Brugada syndrome: report of the second consensus conference: endorsed by the Heart Rhythm Society and the European Heart Rhythm Association. Circulation 111: 659-670.

29. Marionneau C, Couette B, Liu J, Li H, Mangoni ME, et al. (2005) Specific pattern of ionic channel gene expression associated with pacemaker activity in the mouse heart. J Physiol 562: 223-234.

30. Mohler PJ, Yoon W, Bennett V (2004) Ankyrin-B targets beta2-spectrin to an intracellular compartment in neonatal cardiomyocytes. J Biol Chem 279: 40185-40193.

31. Cohen SA (1996) Immunocytochemical localization of $\mathrm{rH} 1$ sodium channel in adult rat heart atria and ventricle: presence in terminal intercalated disks. Circulation 94: 3083-3086.

32. Mohler PJ, Rivolta I, Napolitano G, LeMaillet G, Lambert S, et al. (2004) Nav1.5 E1053K mutation causing Brugada syndrome blocks binding to ankyrin$\mathrm{G}$ and expression of Nav1.5 on the surface of cardiomyocytes. Proc Natl Acad Sci USA 101: 17533-17538.

33. Boixel C, Gavillet B, Rougier JS, Abriel H (2006) Aldosterone increases voltagegated sodium current in ventricular myocytes. Am J Physiol Heart Circ Physiol 290: H2257-H2266. 